\title{
Türkiye`de Orff-Schulwerk Uygulamaları Abant İzzet Baysal Üniversitesi Örneği*
}

\author{
Nesrin KALYONCU* \\ Abant İzzet Baysal Üniversitesi
}

\begin{abstract}
Özet
Carl Orff'un Elementer Müzik ve Hareket Eğitimi tasarımı, 1930'lu yıllardan itibaren gittikçe tanınmış ve çocukların eğitimi için uluslararası düzeyde yaygın kullanım bulmuştur. Ülkemizde bu eğitim anlaylşından haberdar olunması 1950'li yıllara tesadüf etmesine rağmen, çeşitli sebeplerle eğitim/müzik eğitimi planlama ve uygulamalarımı içerisinde tüm bileşenleriyle resmi olarak yer alamamıştır. Söz konusu çalışmaların müzik öğretmenliği ĕgitimi sürecine dahil edilmesi, geleceğin eğitimcilerinin bu yöndeki donanımları açısından büyük önem taşımaktadır. Ayrıca, müzik öğretmeni adaylarının günümüzde okullarda uygulanması öngörülen öğretim programlarının taleplerine cevap verebilmeleri için, müzik alan bilgisi ve öğretim bilgisi yanında, çok çeşitli müziksel davranış biçimleriyle donatılmaları da gittikçe bir zorunluluk halini almaktadır. Bu düşünceden hareketle, 2002 yllında Bolu Abant İzzet Baysal Üniversitesi'nde Elementer Müzik Eğitimi uygulamalarına başlanmıştır. Böylece, ülkemizde sinırlı sayıdaki üniversitede yürütülen elementer müzik çalışmaları zincirine yeni bir halka daha eklenmiştir. Bu makalede, sözü edilen uygulamaların amaç, içerik ve yöntemleri betimlenmekte ve çalışmalarda karşılaşılan sorunlar ortaya konmaktadır.
\end{abstract}

Anahtar sözcükler: Elementer müzik ve hareket eğitimi; Orff-Schulwerk; Abant İzet Baysal Üniversitesi; müzik ögretmenliği ĕgitimi

\begin{abstract}
Carl Orff's design of Elemental Music and Dance Education has been recognized since 1930s and used widely all over the world for the education of children. Although this type of education was first heard in our country in 1950s coincidentally, it has not been incorporated formally with all its components in our educational/music educational plans and practices for various reasons. The integration of these studies in question into the process of music teacher education is important for the training of future educators of music. Furthermore, in order for prospective music teacher to respond to the demands of the curricula in practice at schools today, it has become necessary to provide these candidates with field knowledge of music, teaching skills and various types musical behaviours. With this view in mind, the practice of Elemental Music Education was started at Abant Izzet Baysal University Bolu in 2002, adding a new ring to the chain of elementary music studies already implemented in a limited number of universities in Turkey. At this paper we define the purpose, content and methods of these applications and problems encountered during practice.
\end{abstract}

Keywords: Elemental music and dance education; Orff-Schulwerk; Abant Izzet Baysal University; music teacher education

\footnotetext{
* Bu çalışma, 02-04 Aralık 2005 tarihleri arasında Ankara Üniversitesi ve Çağdaş Drama Derneği tarafından düzenlenen 2. Uluslararası Orff-Schulwerk Sempozyumu kapsamında, Orff Öğretisinin Türk Eğitim Sistemine Yansımaları isimli panelde sunulan bildiriden geliş̧irilmiştir.

* Doç. Dr., Abant İzzet Baysal Üniversitesi, Müzik Eğitimi Bölümü, E-posta: kalyona@gmx.net
} 


\section{Giriş}

Carl Orff (1895-1982)'un Elementer Müzik ve Hareket Ĕgitimi ${ }^{1}$ adı altında toplanan pedagojik fikirleri, 20. yüzyılın ilk çeyreğinde Münih'te filizlenmeye başlamıştır. Orff (1930, s.31), sadece müzik teorisine yönelmiş olan öğrenmeyi tamamlayan veya destekleyen değil, devinimden ve onunla ortak kökleri olan ritimden hareketle yapılandırılacak yeni bir müzik eğitimini hedeflemektedir. İnsanın temel ifade biçimleri olan konuşma, devinme, şarkı söyleme ve dans, çocuklarda birbirlerinden çok keskin çizgilerle ayrılmış eylemler değildir. Orff, bu davranış biçimlerini birbirleriyle iç içe geçmiş olarak elementer müzik kavramında toplamaktadır. "Elementer, Latince elementarius, $<<$ öğelere ait, öğesel, ilk-el, başlangıçta olan $>>$ demektir. O zaman elementer müzik nedir? Elementer müzik hiçbir zaman sadece müzik değildir; hareket, dans ve dil ile birliktedir. Bu müziğe dinleyici olunmaz, onun bizzat yapılması gerekir. O, zihni kurguya dayanmaz, büyük formlara ve mimariye sahip değildir. (...) Elementer müzik tabanda, doğal ve bedenseldir, herkes tarafından öğrenilebilir, tecrübe edilebilir ve çocuğa göredir" (Akt: Gersdorf, 1997, s.53). Buna göre, Elementer Müzik ve Hareket Eğitimi mutlak bir müzik öğretimi olarak değil, bütünlük ilkesinde en temel müziksel deneyimlerin kazandırıldı̆̆ dersinin ön şartlarının oluşturulup müziğe giden yolun açıldığı bir süreç olarak anlaşılmalıdır (Orff, 1931, s.32).

Elementer Müzik ve Hareket Eğitimi kavramıyla birçok kez eş anlamlı olarak da

\footnotetext{
${ }^{1}$ Orff'un eğitim tasarımı yaygın olarak Elementer Müzik ve Hareket Eğitimi olarak ifade edilmesine rağmen, dil/konuşma ögesini de kapsamaktadır. Bundan dolayı bu çalışmada, daha kapsayıcı olması amacıyla Elementer Müzik, Hareket ve Konuşma Eğitimi kavramı önerilmekte ve metin içerisinde de kullanılmaktadır. Yine, ilgili literatürde daha genel bir bakışla Elementer Müzik Eğitimi kavramı da sıkça tercih edilmektedir (Nykrin, 1994; Uçan, 2003).
}

kullanılan Orff-Schulwerk ${ }^{2}$ (Okul Yapıtı ve İşliği) ise, 1930'da Günther Okulu'nda ${ }^{3}$ yapılan doğaçlama uygulamaların nota ve diğer sembollerle yazılıp sabitleştirilmesi düşüncesi sonucunda oluşan esere verilen isimdir (Kugler, 1995). Beş ciltlik Orff-Schulwerk serisinde ve tamamlayıcı kaynaklarında, çeşitli metinler, ritmik ve melodik yapı taşları ve frazeler, şarkılar ve çalg1 parçaları vb. yer almaktadır (Orff \& Keetman, 1950-54). Bu yapıtlar, Elementer Müzik ve Hareket Eğitimi'nde dolaysız olarak kullanılmaktan daha ziyade, kilavuz malzeme niteliği taşımaktadır ve model karakterine sahiptir (Orff, 1932, s.33; Jungmair, 2005). Öğrenci ve öğretmenleri yaratıcı çalışmalar için motive edecek, örneklerle yönlendirecek, ipuçları verecek ve çıkış noktası oluşturacak malzemelerdir. Bundan dolayı, doğaçlamalardan sabitlenmiş olan bu parçaların anlık çeşitleme, ekleme ve çıkarmalarla yaratıcı bir biçimde çalışılmaları ve yeniden doğaçlamayı sağlamaları beklenmektedir.

Orff'un eğitim yaklaşımı 1930'lu yıllardan itibaren Almanya içerisinde gittikçe tanınırken, Günther Okulu'nun çalışmaları ile uluslararası düzeyde de ilgi çekmeye başlamıştır. Günther Dans Grubu'nun 1930 Münih Dans Kongresi ile başlayıp Avrupa Turnesi'ne uzanan gösterileri, bu ilginin uyanmasında önemli roller oynamaktadır (Haselbach, 2002). Bugün, Elementer Müzik ve Hareket Eğitimi kavramı altında toplanan tasarımlarla ilgilenen birçok araştırmacı ve eğitimci, Münih'e ve Almanya'nın çeşitli kentlerinde düzenlenen yaz kurslarına gidip gerekli donanımı sağlayarak Orff-Schulwerk` $i$

${ }^{2}$ Günther Okulu (Günther-Schule), Dorothee Günther’in (18961975) 1924 yılında Münih`te Carl Orff ile birlikte kurduğu Jimnastik ve Dans Okulu'dur. 1944 te kapanan bu okul, Orff un 1924-1932 yılları arasında elementer müzik ve hareket eğitimine ilişsin düşüncelerini hayata geçirdiği yerdir. Geniş bilgi için bkz. Kugler, 2002.

${ }^{3}$ Günther Okulu (Günther-Schule), Dorothee Günther`in (18961975) 1924 yılında Münih`te Carl Orff ile birlikte kurduğu Jimnastik ve Dans Okulu'dur. 1944 te kapanan bu okul, Orff un 1924-1932 yılları arasında elementer müzik ve hareket eğitimine ilişsin düşüncelerini hayata geçirdiği yerdir. Geniş bilgi için bkz. Kugler, 2002. 
kendi ülkelerinde de uygulama yoluna gitmişlerdir. Bunlar içerisinde, Orff un kompozisyon öğrencisi de olan ünlü müzikolog Thrasybulos G. Georgiades(1907-1977)'in 1936 yılında Yunanistan`da başlattığ 1 girişimler, kültürler arası düzeyde belgelenebilmiş ilk çalışmalardır (Kugler, 2002).

1961'de Salzburg Mozarteum Akademisi ${ }^{4}$ bünyesinde açılan Orff Semineri, bu eğitim tarzının Almanya sınırları dışındaki resmi ve kurumsal kabulünün en önemli göstergelerindendir. 1963 y1lında Orff Enstitüsü'ne dönüştürülen bu kurumda, Elementer Müzik ve Hareket Eğitimi için öğretmen yetiştirilmeye başlanmıştır (Gersdorf, 1997). Bu enstitü, Orff eğitim anlayışının uluslar arası yayılımında da çok önemli görevler üstlenecektir. Çeşitli ülkelerden öğrenci, öğretmen, araştırmac1, terapist, müzik ve dans pedagogları, bugün de olduğu gibi burada düzenlenen programlara ve yaz kurslarına katılarak Orff-Schulwerk'i didaktik ve metodik yönleriyle öğrenme firsatı bulmuşlardır.

Aynı yıllarda Carl Orff da, eğitim anlayışını ve materyallerini tanıtmak, yayılmakta olan ilgiyi daha da artırmak amacıyla başka ülkelerde konferanslar vermiştir. Bunların bazılarını önce öğrencisi, ardından çalışma arkadaşı ve OrffSchulwerk in ortak yazarı olan Gunild Keetman (1904-1990) ile birlikte gerçekleştirmiştir. 1962 y1lında Japonya ve Kanada' da konferanslar verir; bir yıl sonra Portekiz'de yapılan çalışmaları 1966 Mısır ve Senegal konferansları izlemiştir. Böylece, Orff'un elementer müzik ve dansa ilişkin düşünceleri dünyanın dört bir yanında tanınmaya başlar.

Türkiye'de Orff-Schulwerk'ten haberdar olunması ise 1950 'li yıllara rastlamaktadır ve bugün ulaştığı konumu, o yıllarda başlayıp oldukça yavaş bir hızda artıp çeşitlenen

\footnotetext{
${ }^{4}$ Bu akademi bugün, Mozarteum Müzik ve Güzel Sanatlar Üniversitesi'ne dönüştürülmüştür.
}

çalışmalara borçludur. $\mathrm{Bu}$ alanda ilk girişim, Orff un eğitim anlayışını kendisinden öğrenen ve Türk E $\breve{g}++$ itim Derneği Ankara Koleji'nde uzunca yıllar uygulayan Muzaffer Arkan(19232006)'a aittir (Öztürk, 2005). ${ }^{5}$ Arkan, 1951 yılından itibaren 6 yıl boyunca değişik aralıklarla Almanya'da Orff ile buluşmuş ve bazı yaz kurslarına katılmıştır. Bunun yanı sıra, Orff anlayışında işlediği Türk ezgilerinin kayıtları da yurt dışında seslendirilmişsir. Arkan, 1956 yılında Orff-Schulwerk'i Çocuklar İçin Okul Ödevi şeklinde Türkçe'ye çevirmiş (Uçan, 2003), fakat bu çalışması yayınlanamamıştır.

Arkan`ın girişimlerine rağmen, Elementer Müzik ve Hareket Eğitimi Türkiye'de uzunca yıllar tanınıp yaygınlaşamamışıtır. Onun kitlelerin hizmetine sunulamamasının, burada hepsini tartışmanın kapsam açısından mümkün olmadığ 1 çok çeşitli sebepleri vardır. Bu sorun irdelenirken, öncelikle sosyo-kültürel etkenler göz önünde tutulmalıdır. Fakat, burada vurgulanmak istenen, kültür farklılığ1 veya yabancı kültür ürünlerinin kullanımı sorunu değildir. Nitekim, Orff'un çocuklar için standart hale getirdiği çalgılar farklı müzik kültürlerinden, özellikle de Avrupa Müzik Kültürü dışında kalanlardan derlenmiştir (Kugler, 2002). Yine, Orff $u$ başka kültürlerde uygulamanın Schulwerk materyalini aynen aktarmak olmadığı, eğitim prensiplerinin ve yöntemin alınması gerektĭgi, yaşama geçtiği ilk yıllardan itibaren bilinmektedir (Georgiades, 1936). Ayrıca, Türk Halk Müziği ve danslarındaki uygulamaların bir kısmı, Orff un temel aldığ müzik ve hareket birlikteliği, ostinato ya dayalı müzik yapma gibi bazı noktaları bizim kültürümüz için de geçerli olduğunu göstermektedir. Onun için, Elementer Müzik Eğitimi konseptinin taşıdığ 1 Alman markası, Türk Eğitim Sistemi içerisine alınmamasının birincil

\footnotetext{
5 Bununla birlikte, Orff-Schulwerk'in Türkiye'de ilk kez E. Zuckmayer tarafından tanıtıldığına dair bilgiler de bulunmaktadır (Uçan, 2003)
} 
sebebi değildir. Ayrıca, okullarımızdaki müzik eğitiminin Batı Müziği eksenli olması da, böylesine bir girişimin önünü açar niteliktedir.

Burada dikkat çekilmek istenen esas sorunsal, insan biçimlendirme zihniyeti ve alışkanlıklarımızla ilgilidir. Ailede genel terbiye kazandırmaktan okula kadar her alandaki eğitim sürecinde, yetişmekte olan çocuk toplumsal şemalar içerisinde otoriteye sunulmakta, bireyselleşme ihtiyacına yeterince önem verilmemektedir. Müzik eğitimimizin 21. yüzyıl başında bile salt öğretmen merkezli bir görünüm sergilemesi (Kalyoncu, 2002), bu bakış açısının formal eğitimdeki uzantısının önemli kanıtlarındandır. Feodal çizgileri güçlü olan bir toplum, kendini ifade etmeyi, bireyin ihtiyaçlarını ve yaratıcıllğı merkeze alan bir eğitim modelini, bunun için gerekli olan düşünsel dönüşümü gerçekleştirmeden kabul edebilir mi? Kanımızca, cevaplanmasi gereken esas soru budur. Elementer Müzik Eğitimi süreci, geleneksel ders profilinden kesin çizgilerle ayrılmakta, birçok özelliğiyle "bilginin yapılandırılması, işbirliği, esneklik, bireyselliğe saygı ve yaratıcılık" (Aydın, 2006, s. 60) gibi kavramları öne çıkaran çağcıl eğitim anlayışına yaklaşmaktadır. Müzik eğitimi uygulamalarımızın yenilikçi modellere yeterince açık olmaması ve geleneksel olarak aktarılan uygulama biçimlerinin de gittikçe klişeleşmesi, kabul sorununun başlıca sebeplerindendir.

Bazı finansal etkenler de Orff-Schulwerk in yayılımını zorlaştırmıştır. Diğer müzik çalışmalarında olduğu gibi, elementer müzik alıştırmalarında kullanılacak çalgıların ve kaynak kitapların maliyetleri de oldukça yüksektir. Bundan dolayı, ülkemizde Orff Elementer Müzik ve Hareket Eğitimi uzunca yıllar sadece birkaç özel okul çatısında sınırlı sayıdaki kişiye ulaşabilecek şekilde sürdürülebilmiştir. Arkan`dan sonra Liselotte Sey, Ankara'da kurduğu Özel Liz Teyze Çocuk Yuvası'nda 1980'den itibaren yıllarca bu eğitim anlayışının uygulanmasını ve
Orff un adının duyulmasını sağlamıştır (Sey-Uluç, 2002). Günümüzde Orff-Schulwerk 'in tanıtılmasında önemli roller oynayan çalışmalar da yine özel bir eğitim kurumunda başlatılmıştır. 1999 y1linda Özel Avusturya Liseliler Vakfi İlkögretim Okulu'nda yoğun olarak başlayan elementer müzik çalışmaları, organize bir adımın da öncüsüdür: Vakfın desteğiyle 2001 yılında kurulan İstanbul Orff-Schulwerk Eğitim ve Danışmanlık Merkezi nin, ülkemizde bu eğitim yaklaşımının tanınmasına önemli katkıları olmaktadır. ${ }^{6}$

Yukarıda ortaya konan nedenlerle birlikte, Uçan'ın (2003) da tartıştığı gibi, ülkemiz eğitim politikaları Orff anlayışının tanınmasını çok büyük ölçülerde zorlaştırmıştır. Orff-Schulwerk, eğitim sistemi içerisinde on yllardan beri görmezlikten gelinmiş, benimsenmemiş ve kurumsallaşmamıştır. Okul müzik dersleri için 20. yüzyılda kullanılmış olan öğretim programları irdelendiğinde, Elementer Müzik Eğitimi'nin bunlar içerisinde, -genellenemeyecek kadar sınırlı sayıdaki ibareler dışında- tüm bileşenleriyle resmi olarak yer almadığı saptanmaktadır [Kültür Bakanlığı, 1938; Milli Eğitim Bakanlığı (MEB, 1948; MEB 1952; MEB, 1962; MEB, 1968; MEB, 1994)]. Buna bağlı olarak, ilgili çalışmalar ülke çapında organize edilmemiş, öğreticilerin eğitimi ve gerekli malzemenin temini için yasal düzenlemeler de yapılmamıştır. $\mathrm{Bu}$ eğitim yaklaşımı kurumsallaşamadığından, ülkemizdeki uygulamalar çoğunlukla kişisel girişimlerle sınırlı kalmıştır.

Çocukların hizmetine sunulmuş olan OrffSchulwerk in pedagojik değerinin fark edilmeyip

\footnotetext{
${ }^{6}$ Istanbul Orff-Schulwerk Ĕ̈itim ve Danışmanlık Merkezi, çok çeşitli eğitim etkinlikleri düzenlemektedir. Bunun en başında, düzenli olarak sürdürülen Orff-Schulwerk kursları gelmektedir. Yine, merkezin çıkarmış olduğu bültende, Info, bu alandaki bilimsel ve uygulamaya dönük didaktik yazılarla, yapılmış olan etkinlik haberleri düzenli olarak yayımlanmaktadır. Oluşturulan elektronik haberleşme ağı üzerinden de üyelerini kurs ve konferanslar hakkında bilgilendirmektedir. Ayrica bu merkezin, I. ve II. Uluslararası Orff-Schulwerk Sempozyumlarının gerçekleştirilmesinde de öncü rolleri olmuştur.
} 
eğitim sistemimiz içerisine kaynaştırılamamasında, müzik eğitimi anlayışımızın da etkisi vardır. Ülkemizde tutarlı müzik eğitimi politikaları izlenmemekte, müzik eğitimi planlama ve uygulamaları süreklilik ilkesine dayanmamakta ve eğitim alan tüm bireyleri bütüncül olarak kapsamamaktadır. Bunun sonucu olarak, müzik eğitimi süreçleri tabandan tavana doğru olmak yerine, genellikle tam tersi yönde düzenlenmektedir (Dinçer, 1988; Uçan, 2003). Müzik eğitimi tartışmalarının gündemi, sıklıkla akademik düzeydeki müzik eğitimi sorun ve sorunsalları tarafından belirlenirken, okul öncesi ve ilköğretim çağındaki çocukların müziksel eğitim ihtiyaçları derinlikli olarak tartış1lıp, bu yönde gereken tüm önlemler alınamamaktadır. Ülkemizde, okul öncesi ve ilköğretim için günümüzde bile müzik öğretmeni yetiştirilmemesi ve bunu sağlayacak yan dal programlarının kapatılmış olması, bunun en güçlü kanıtlarından birisi değil midir?

Ülkemizde, Orff-Schulwerk in yaygın olarak kullanıldığ1 okul öncesi dönemde tüm bireyleri kapsayan eğitim uygulamalarının yola koyulamaması da, kabul sorununun önemli sebeplerindendir. Günümüz Türkiye'sinde erken çocukluk eğitiminin 4-6 yaş arasındaki bireylerin sadece \% 16`sına ulaşıyor olması (Türk Sanayicileri ve İşadamları Derneği [TÜSİAD], 2005), bu problemin hala geçerliliğini koruduğunu göstermektedir. Genel anlamda bir eğitim bilinci ve ihtiyacının oluşmamış olması ve erken çocukluk eğitimi programlarının ülke çapında organize edilememesi müzik eğitimine de yansımakta, dolaysız olarak, kabul görmüş uygun müzik eğitimi yaklaşımlarından yararlanılmasının önüne geçmektedir.

Elementer Müzik Eğitimi çalışmalarının müzik öğretmenliği programlarında sistematik olarak yer almaması da, yaygınlaşmasını olumsuz olarak etkilemiştir. Uçan (2003), bu programlar içerisinde ilk Orff-Schulwerk çalışmalarının E.
Zuckmayer (1890-1972) tarafindan 1950’li yıllarda başlatıldığını bildirmektedir. Ayrıca bundan önce, Ritmik Jimnastik ve Dans derslerinin J. R. R. Marx (1882-1964) ve P. Hindemith'in (1895-1963) önerileri doğrultusunda, müzik öğretmeni yetiştiren programlara 1936 yllında girdiğini de belirtmektedir. Ritmik Jimnastik, daha sonra 1941 Gazi Orta Öğretmen Okulu ve Terbiye Enstitüsü Müzik Şubesi Müfredat Programı ve 1980 Gazi Yüksek Öğretmen Okulu Müzik Bölümü Programı'nda da karşımıza çıkmaktadır (Programları aktaran: Uçan, 1996). Bununla beraber, oldukça kısa formüle edilmiş ders içeriklerinde Elementer Müzik ve Hareket Eğitimi veya OrffSchulwerk kavramları açık olarak yer almamaktadır. Buna dayanarak, müzik öğretmeni yetiştirme programlarındaki elementer müzik ve dans çalışmalarının uzunca yıllar dar kapsamda kaldığını ve süreklilik kazanıp gelenekselleşemediği söylemek mümkündür.

Müzik öğretmeni yetiştiren kurumlarda daha geniş soluklu atılımlar, 20. yüzyılın son çeyreğine tesadüf etmektedir. 1980 yılında Buca Eğitim Fakültesi Müzik Eğitimi Bölümü’nde Orff çalgıları yapımına başlanması bu bağlamda anılacak ilk çalışmalardandır (Say, 1985). Bu çalgıların ülkemizde üretilmesi, her şeyden önce alım gücünü olumlu yönde etkilemiştir. Yine, 1990`1ı yıllarda Gazi Üniversitesi Müzik Eğitimi Bölümü’nün düzenlediği Orff-Schulwerk seminerleri, müzik öğretmenliği programlarındaki öncü etkinliklerdendir (Uçan, 2003). Ardından, Buca Eğitim Fakültesi’ndeki çalışmalar 1997 yılından itibaren Elementer Müzik Eğitimi anlayışına doğru yönelmiş (Bilen, Özevin \& Uçal, 2003), üniversite düzeyinde sürdürülen bu çalışmalara, 1998 yılında Anadolu Üniversitesi'nin uygulamaları eklenmiştir.

Günümüzde, müzik öğretmeni yetiştiren çeşitli üniversitelerde Orff'un eğitim tasarımına ilgi gittikçe artmaktadır. Elementer Müzik Eğitimi 
anlayışının, günümüz eğitim uygulamalarını gittikçe daha çok etkileyen Çoklu Zeka Kuramı'nın taleplerine büyük ölçülerde cevap veriyor olması da (Calvin \& Campbell, 1998), bu ilgiyi teşvik eder niteliktedir. Bununla birlikte, uygulanan merkezi müzik öğretmenliği programlarında tümüyle Elementer Müzik, Hareket ve Konuşma Eğitimi'ni konu alan bir ders açıkça yer almamaktadır. $\mathrm{Bu}$ durum, müzik öğretmeni yeterlikleri açısından bakıldığında bir eksikliği işaret etmektedir. Müzik öğretmeni adaylarının, günümüzde okullarda uygulanması öngörülen öğretim programlarının taleplerini yerine getirebilmeleri için, müzik alan bilgisi ve öğretim bilgisi yanında, çok çeşitli müziksel davranış biçimleriyle donatılmaları da zorunluluk haline gelmektedir (Kalyoncu, 2004b). Müziksel eylem biçimleri sadece çalma ve söylemeye indirgenmiş bir müzik öğretmeni yetiştirme süreci, bu yeterlikleri kazandırmaktan çok uzaktır. Bunun için, müzik öğretmen adaylarının müziksel yaratıc1lık ve müziksel dönüştürme davranışları açısından da yeterince teşvik edilmesi gerekmektedir. $\mathrm{Bu}$ bakış açısından hareketle, Elementer Müzik, Hareket ve Konuşma Eğitimi kapsamındaki çalışmaların bu yöndeki kazanımlara olanak sağlayacağı düşünülmektedir.

\section{Amaç ve Kapsam}

Bu makalede, Abant İzzet Baysal Üniversitesi Eğitim Fakültesi Güzel Sanatlar Eğitimi Bölümü’nde yapılan Elementer Müzik, Hareket ve Konuşma Eğitimi çalışmalarının sunumu amaçlanmaktadır. Bu kapsamda, öğretmen eğitimi programlarında sürdürülen Orff-Schulwerk alıştırmalarının başlangıcı hakkında bilgiler verilmekte, güncel çalışmaların amaç, içerik ve yöntemleri ana hatlarıla betimlenmektedir. Ayrıca makalede, öğretim üyesi ve öğrencilerin bu uygulamalarda karşılaştıkları problemler de aktarılarak başka uygulayıcılarla deneyimlerin paylaşımı da amaçlanmaktadır. Öğrenci düşüncelerinin tespitinde, 2003-2004 Öğretim Yllı'nda "Oyun, Dans ve Müzik", "Müzik Öğretimi”; 2004-2005 ve 2005-2006 Öğretim Yılı'nda ise "Okul Çalgıları-I" ve "Özel Öğretim Yöntemleri-II" derslerinde öğrencilerden alınan yazılı naratif dönütler kullanılmıştır.

\section{Abant İzzet Baysal Üniversitesiin ne Orff-Schulwerk Uygulamalan}

\section{Başlangıç Çalışmaları}

Bolu'da 1992 yılında kurulmuş oldukça genç bir kurum olan Abant İzzet Baysal Üniversitesi nde, Orff'un Elementer Müzik ve Hareket Eğitimi`ne ilişkin fikir ve materyallerle karşılaşma ve uygulama oldukça yenidir. 1998 yılında Yükseköğretim Kurulu tarafından Milli Eğitimi Geliştirme Projesi kapsamında Eğitim Fakültesi ne hibe edilen bir grup Orff çalgısı, bu yolun ilk taşlarını oluşturmaktadır. Üniversitenin, Elementer Müzik ve Hareket Eğitimi`ne ilişkin unsurlarla kuruluş yıllarında karşılaşması, söz konusu fikirleri erken bir dönemde bünyesine almaya başlaması ve gittikçe geliştirip olgunlaştırması için bir şanstır.

Elementer müzik alıştırmaları kapsamına dahil edilebilecek aktif çalışmalar ise, makalenin yazarının Münih Üniversitesi`nde sürdürdüğü Müzik Pedagojisi öğrenimini tamamlayarak Bolu'da görev alması ile 2002 yılında öğretmen eğitimi çerçevesinde başlamıştır. Orff-Schulwerk içerikleri, diğer üniversitelerde de yapıldığ (Bilen, 2003), müzik öğretimi ile ilgili dersler içerisine entegre edilmeye başlanmıştır. İlk olarak 2002-2003 Güz Yarıyılı’nda sınıf öğretmeni adaylarıyla yapılan, ardından Bahar Yarıyılı'nda da Zihin Engelliler Eğitimi Anabilim Dalı'nda yürütülen "Müzik Öğretimi" derslerine, Orff"un eğitim anlayışı kapsamındaki bazı içerikler dahil edilmiştir. Bunlar, ritmik egzersizler, tekerlemelerin ve sözel birimlerin devinimle çalışılması, beden çalgılarının ve Orff çalgılarının 
kullanımı, devinim ve dansa dönüştürme ve idiophonlar geliştirme olarak sıralanabilir.

İstanbul'da 2003 yılında yapılan $I$. Uluslararast Orff-Schulwerk Müzik ve Dans Pedagojisi Sempozyumu'ndaki heyecan da, çalışmalara devam etmek ve gittikçe çapını genişletmek için bizi motive edip yüreklendirmiştir. Makalenin yazarının 2003-2004 Güz Yarıyılı`nda Müzik Eğitimi Anabilim Dalı`nda pedagojik ders yükümlülüğünü üstlenmesiyle, ilgili derslerin bir kısmına da OrffSchulwerk içerikleri dahil edilmeye başlanmıştır (Kalyoncu, 2004a). Aynı dönem, "Oyun, Dans ve Müzik” adı altında seçmeli bir çalışma da, Okul Öncesi Eğitimi Anabilim Dalı nda yürütülmüştür.

\section{Günümüzdeki Durum}

Aktüel çalışmalarımızı, Eğitim Fakültesi'nde ağırlıklı olarak Müzik Eğitimi Anabilim Dalı'nda sürdürmeye çalışmaktayız. Uygulanan merkezi Müzik Öğretmenliği Lisans Programı'nda, tümüyle Elementer Müzik ve Hareket Eğitimi'ni konu alan bir ders bulunmadığından, yola koyulan uygulamalar "Oyun, Dans ve Müzik" ile "Özel Öğretim Yöntemleri” gibi derslere entegre edilmektedir. Bununla birlikte, "Okul Çalgıları-I" dersi iki yıldan bu yana Orff Çalgıları olarak verilmekte, beden enstrümanları ile Orff ritim ve ezgi çalgıları elementer müzik yapma anlayışında çalışılmaktadır. Orff-Schulwerk, Zihin Engelliler Eğitimi Anabilim Dalı `nda da "Müzik Öğretimi" dersleri kapsamında daha sınırlı bir çerçevede ele alınmaktadır.

Çalışmalara katılan öğrencilerin ilgili ön öğrenmeleri kayıtlı oldukları programa göre değişmekte, müziksel, devinişsel ve transformatif davranışlar açısından giriş düzeyleri farklılık göstermektedir. Zihin engelliler öğretmeni yetiştiren programlardaki öğrencilerin müziksel hazır bulunuşluk düzeyleri müzik bölümündeki öğrencilere kıyasla daha sınırlıdır. Buna karşın, bu bölümün programında elementer anlayıştaki öğrenme yaşantılarını son derece destekleyen "Yaratıcı Drama" dersi bulunurken, müzik öğretmenliği programında böyle bir çalışma yer almamaktadır.

Fakültemizde sürdürülen çalışmaların amaçları, içerikleri ve yöntemleri ile uygulamalarda karşılaşılan sorunlar, genel bir bakış açısıyla aşağıda sunulmaktadır.

\section{Amaçlar}

Orff'un eğitim konsepti Elementer Müzik ve Hareket Eğitimi olarak nitelenmesine rağmen, Holzheuer'in (1979) de belirttiği gibi "ne müzik dersinin kazandırmak istediği spesifik müziksel yetenek, yeterlik ve anlayışı, ne de spor dersinin içerdiği anlamda bedensel eğitimi amaçlar. Müzik ve Hareket Eğitimi dersi, çocuktaki duygusal güçleri açığa çıkarmayı ve geliştirmeyi, onun yaratıcı yeteneklerini teşvik etmeyi ve sosyal öğrenmeyi mümkün kılmayı hedefler" (s.118). Buradan da anlaşılabileceği gibi, bu eğitim sürecinde genel-eğitsel amaçlar öne çıkmaktadır. Üniversitemizde yapılan çalışmalar da, öncelikle bu amaçlar üzerine kurulmaktadır. Bununla birlikte, bu alıştırmalar öğretmen yetiştirme programlarının genel amaçlarından bağımsız olarak düşünülemeyeceğinden, kazanımların öğretmen adayları açısından işlevsel bir özellik taşımasına da itina gösterilmektedir.

Yaptığımız çalışmalar aşağıdaki temel amaçlar üzerine kurulmaktadır:

1. Elementer Müzik ve Hareket Eğitimi'ni genel hatlarıla tanıyabilme

2. Elementer anlayışta ve düzeyde müziksel yaşantılar geçirebilme

3. Farklı duyuları koordineli olarak kullanabilme (işitsel, görsel, dokunsal alg1 ve kinestetik alg1)

4. Konuşma, söyleme, devinme, çalma, dönüştürme vb. gibi çeşitli davranış biçimlerini girişik olarak gerçekleştirebilme 
5. Yaratıcı ve özgün müziksel çalışmalar yapabilme

6. Konsantrasyon yeterliğini artırabilme

7. Bireysel ve birlikte çalışma alışkanlıklarını geliştirebilme

8. Okul müzik derslerinde Orff" un pedagojik fikirlerini içerik ve yöntem olarak kullanabilmek için bilinç ve temel donanım kazanabilme

\section{İcerikler}

Orff anlayışındaki elementer müzik çalışmaları, birden fazla duyu işe koşulduğundan ve farklı ifade alanlarının öğelerini buluşturduğundan çok yönlü ve çok boyutludur (Regner, 1995). Abant İzzet Baysal Üniversitesi Eğitim Fakültesi'nde bu anlayışta yapılan çalışmalarda da, konuşma, öyküleme, ritmik çalışma, şarkı söyleme, ezgileme, devinme, dans etme, çalma, eşlikleme, canlandırma, resme dönüştürme ve grafikleme vb. gibi aktiviteler girişik olarak işlenmektedir.

$\mathrm{Bu}$ uygulamalarda Orff'un pedagojik fikirleri ve ipuçları şekillendirici olurken, malzeme seçiminde kültürel birikim dikkate alınmakta, elementer müzik çalışmalarına uygun gelenek, materyal ve çalgıların kullanımından yola çıkılmaktadır. Türk atasözleri, tekerlemeleri, çocuk ve halk ezgileri ile dansları ve basit Türk vurma çalgıları öncelikle tercih edilmektedir. Buradan hareketle, Orff-Schulwerk kaynaklarında yer alan müziksel materyallerin çalışılmasına doğru gidilmektedir.

Uygulamalarımızda ağırlık verdiğimiz davranış biçimleri aşağıdaki ana noktalarda toplanmaktadır. Burada sunulan aktiviteler uygulamada iç içe geçmiş olarak ele alındığından, aşağıdaki sıralama hiyerarşik bir aşamalandırma olmayıp, sistematik sunum zorunluluğunun getirmiş olduğu bir ayrıştırmadır.

\section{a) Konuşma ve Şarkı Söyleme}

Herkes tarafından bilindiği gibi, ses insanın en doğal ve içkin enstrümanıdır; dil ise kendini ifade için kullanılan en temel ve birincil araçtır. Bundan ötürü, çalışmalarda söz ve konuşma ögeleri önemli bir yer tutmakta, ayrıca Zihin Engelliler Eğitimi Anabilim Dalı'nda bu çalışmalara daha da ağırlık verilmektedir. Kelime, nida, cümle, dörtlük, tekerleme ve sayışmaların devinimle birlikte çeşitli hız ve dinamiklerde doğaçlama konuşulması çıkış noktamızı oluşturmaktadır. Bu sözel materyaller üzerinden dil ve müziğin ortak ögesi olan ritim çalışmalarına geçilmektedir. $\mathrm{Bu}$ aşamada çok çeşitli yaklaşımlar mümkündür: örneğin ritmik konuşmalar harekete dönüştürülmekte, beden ve vurma çalgıları ile çalınmakta, ardından da Orff ezgi çalgıları üzerinde bu sözel birimlerle doğaçlama melodi çalışmaları gelmektedir.

Hikaye ve masallar okul öncesi dönemdeki çocukların eğitiminde sıkça kullanıldığından, bu yaş çocuklarını hedefleyen hikaye çalışmaları da yapılmaktadır. Öğrenciler tarafından oluşturulan masal ve öyküler, çocukların gelişim düzeyine uygunluk açısından irdelendikten sonra çok yönlü olarak çalışılmaktadır: ritmik konuşma, ezgileme, ses zeminleri oluşturma, olay ve karakterlerin ses, devinim ve beden diliyle canlandırılması, resme dönüştürme gibi aktiviteler örnek olarak verilebilir.

Her düzeydeki müzik dersinde ağırlıklı konumda bulunan içeriklerin başında şark1 söyleme gelmektedir. Öğretmen adaylarıyla, aynı yaklaşımla şarkı söyleme eylemini zenginleştirecek etkinlikler de yapılmaktadır. İleride çalışacakları okullarda uygulamaları amacıyla, şarkılar beden ve Orff çalgıları ile eşlik etme, vokalize çeşitleme ve eşlik, canlandırma, devinim ve dans gibi aksiyonlar eklenerek işlenmektedir. 


\section{b) Çalma ve Eşlik Etme}

Çalma etkinliklerine, Orff-Schulwerk anlayışında önemli bir yeri olan beden çalgılarıyla başlanmaktadır. $\mathrm{Bu}$, bireyin müzik yapmak için doğal ve temel gereçlere sahip olduğunu ve bedeninden çeşitli tınıları elde etme imkanını fark etmesi açısından büyük önem taşımaktadır. Bütün beden üzerinde yapılan bu çalışmaların keşfedici yanı öğrencileri motive etmektedir ve söz konusu çalışmalara katılım bütün bölümlerde oldukça yüksektir. Ses elde edilen çeşitli materyaller ve eşyalar gittikçe bu çalışmalara eklenmekte, ardından da def, tahta davul, ritim kutuları ve çubukları vb. gibi birçok çalgıdan oluşan Orff ritim çalgıları gelmektedir. Son aşamada, zıt tınıların elde edilebildiği ağaç ve metal levhalı vurma ezgi çalgıları öğrenilmektedir. Blok flüt bazı çalışmalara dahil edilmesine rağmen, bölümde ayrı bir ders olarak verildiğinden Orff çalgıları ile birlikte öğretilmemektedir.

Çalma eylemine, notalar yerine sözcük ve cümlelerle başlanmaktadır. Başlangıç çalışmalarımız da konuşulan cümlelerin enstrümanlara aktarımı esnasında öğrenciler doğaçlama yaparak kendi ritim ve melodilerini yaratmaktadırlar. Buradan hareketle, ritmik ve melodik frazelerin, çocuk şarkılarının, basit halk türküleri ile çalgı parçalarının ve OrffSchulwerk'ten seçilmiş yapıtların çalınmasına doğru gidilmektedir. Bu parçalar, röprodüksiyon anlayışından farklı olarak, ritmik ve melodik çeşitleme, yeni ostinatolar bulma, yeni partiler ekleme vb. gibi çeşitli yöntemlerle canlı yapılar haline dönüştürülmektedir.

Konuşulan cümlelere, hikayelere, şark1 veya çalgı parçalarına, devinime veya dinleti örneklerine eşlik edilmesi de diğer bir aktivitedir. Eşliklerde de doğaçlama esas yöntemdir; öğrencilerin kendi yaratılarını oluşturmalarına firsat verilmekte, başlangıçta genellikle bordun ve ostinato modellerden yola çıkılmaktadır.

\section{c) Devinme ve Dans}

$\mathrm{Bu}$ yöndeki çalışmalarda, doğaçlama devinim/dans ve doğaçlamaların sabitlenerek kurgulanması temel yöntemlerimizi oluşturmaktadır. Uygulamalarımız iki ana kola ayrılır: birinci çalışma tipinde hareketten müziğe varmak esastır. Beden devinimlerine sözcük, ses, ritim/ritim kalıpları veya melodiler bulma gibi aşamalı çalışmalar örnek olarak verilebilir. Harekete göre müzik çalışmalarında ise, vücut devinimlerinin dolaysiz olarak beden perküsyonuna, Orff çalgıları üzerinde ritmik veya melodik birimlere dönüştürülmesi esastır.

İkinci çalışma tipinde ise müzikten veya müziksel ögelerden harekete varmak amaçlanmaktadır. Mekânda toplu halde söylenen sözel yapılarla, ritimlerle veya müzik eşliğinde yürüme, koşma, sıçrama, atlama veya durma vb. gibi temel beden hareketleri çeşitli yönlerde çalışılmaktadır. Çocuk şarkıları, kolay halk türküleri, hafif müzik parçaları veya klasik müzik eserleri gibi çeşitli tür ve biçimlerdeki yapıtların bütününe veya ölçü, ritim, form vb. gibi belli bir unsuruna göre de doğaçlama hareket edilmektedir.

Ardından, devinim ve dans doğaçlamaları sabitlenerek düzenlemeler yapılmakta, koreografiler de oluşturulmaktadır. $\mathrm{Bu}$ çalışmalarda, yapılandırılmış/kurgulanmış mevcut hareket süreçleri de ele alınmakta, bazı yaygın çocuk dansları ve halk dansları da ilgili dersler kapsamında işlenmektedir.

\section{d) Canlandirma}

Canlandırma çalışmalarında müziğin mimari malzemesi ses ile ilgili özelliklerin, müziksel ve müzik dışı içeriğin çalışılması başta gelir. Ses kaynakları ve türleri ile birlikte, süre, yükseklik, hız, şiddet, renk gibi temel ses parametrelerinin işlenmesinde canlandırma yöntemi sıklıkla tercih edilmektedir. Çeşitli dörtlük ve şiirlerin, şarkıların dramatize edilmesi de bu kapsamdaki çalışmalarımızdandır. C. Saint \& Saëns (1835- 
1921) "Hayvanlar Karnavalı" örneğinde olduğu gibi, içeriği ile canlandırma çalışmasına özendirebilecek orkestra eserleri de ele alınmaktadır. Taklit etme, beden dili, olay ve karakterlerin canlandırılması bireyin ses ve müziğe ilişkin olguları ve tematik içeriği kendi deneyimi yoluyla yaşayarak anlamasını kolaylaştırmaktadır.

\section{e) Ses Materyalleri İnşa Etme}

$\mathrm{Bu}$ çalışmaların amacı, okul öncesi ve ilköğretim müzik derslerinde kullanılabilecek ses materyalleri hazırlamaktır. Çoğunlukla idiophon özelliği taşıyan bu araçların yapımında, tahta, karton, taş gibi malzemelerin yanı sıra genellikle yoğurt kab1, cam ve plastik şişe, ambalaj lastiği gibi atık malzemeler kullanılmaktadır. Öğrenciler bu çalışmalarla, materyal üretimi imkanlarını ve çeşitliliğini somut olarak görmektedirler. Ayrıca ürettikleri araçları ve basit çalgı tasarımlarını, Orff-Schulwerk aktivitelerinde de bizzat kullanmaktadırlar.

\section{Yöntemler}

Orff anlayışına uygun olarak, öğrenci merkezli ders tipi kendiliğinden çalışmaların odağına oturmakta ve tercih edilmektedir. Öğretim üyesi rehber konumundadır; yani çalışmanın ilke, amaç, içerik ve yöntemini belirlemekte, "Ne?" yapılacağını bildirmekte, "Nasıl?" yapılacağını ise aktif çalışma esnasında öğrencilerden gelen reaksiyonlar belirlemektedir. Böylelikle, her çalışma özgün bir süreç oluşturmakta ve katılımcıların kendilerine ait ürünler yaratmakta olduğu fikri pekişmektedir. Bunun aynı zamanda, öğrenenin sorumluluk ve risk alma açısından gelişimine de katkı sağlayacağı düşünülmektedir.

Her çalışma süreci kendi içinde aşamalara ayrılmaktadır ve amaca göre bu evrelerin sayısı değişebilmektedir. Öncelikle, grup elemanlarının birbirini tanıması için devinim veya çeşitli oyunlardan oluşan isınma evresi gerçekleştirilir. Çalışılacak içeriğe hazırlayan doğaçlama giriş aktivitelerinden sonra, ağırlıklı olan esas etkinlik evresi gelmekte ve büyük grupla çalışılmaktadır. Ardından küçük grup çalışmalarına geçilmekte ve öğretim üyesinin rehberliğinde yaratıcı çalışmalar yapılmaktadır. Tüm grupların ürünlerinin sunulmasının ardından, rahatlama egzersizleri gelmektedir. Son aşamada ise çalışma süreci tartışılmakta, uygulamadan teorik çıkarımlar yapılmaktadır.

$\mathrm{Bu}$ aşamalardaki uygulamaların ana yöntemleri ise, keşfetme, doğaçlama, oyun, yaşayarak ögrenme ve tartışma'dır. Doğaçlama, Jungmair in (2002) de vurguladığı gibi plansızlık ve herkesin istediğini yapması anlamına gelmemekte, belli ilkelere ve belirlenmiş oyun kurallarına dayanmakta, rehber öğretmenin yönergeleriyle biçimlenmekte ve bireylerin müziksel, devinişsel ve duygusal yönlerdeki içsel yaşantılarını ortaya çıkarmayı amaçlamaktadır.

Çalışmalarda, öğretmen merkezli derste alışılan, öğretmen ve sınıfın karşı karşıya olduğu "cephe formu" (Peterßen, 2000, s.406) yerine, çok çeşitli iletişim biçimlerine olanak verecek sosyal formlar tercih edilmektedir. Bu bağlamda, partner çalışması, büyük ve küçük grup çalışması, çember ve yarım çember formu yanı sıra bazen de $U$ formu kullanılmaktadır. Çalışmalarda sıra veya sandalyeler yerine zeminin kullanılması da, ilk karşılaşmada öğrencileri oldukça şaşırtmaktadır.

Öğretmen adaylarının edindikleri beceri ve bilgileri okul ortamında nasıl uygulayacaklarını öğrenmeye çalıştıkları öğretme denemeleri de, yapılan etkinliklerin önemli bir kolunu oluşturmaktadır. Kazanılan deneyimler, belli yaş gruplarına göre ele alınmakta, yapay olarak oluşturulan sınıf ortamlarında hayata geçirilmektedir. Böylece öğrenciler, öğrendiklerinin ne kadarını hangi şekilde okul ortamına taşıyabilecekleri üzerinde de düşünmektedirler. Öğretme deneyimlerinden 
sonra öğretmen adaylarının performans1 tartışılmakta, diğer öğrenciler ve öğretim elemanı tarafindan gerekli dönütler verilmektedir.

\section{Paylaşım Etkinlikleri}

Uygulamalarımızın önemli uzantılarından birisi de, çalışmalarda oluşan ürünlerin sergilenerek başkalarıyla paylaşımıdır. Fakülte ve okullarda gerçekleştirdiğimiz gösteri veya sergi gibi etkinliklerde çalışmalarımızı tanıtıcı açıklamalar da yapılmaktadır. Üniversite bünyesinde ve dışında gerçekleştirdiğimiz çalışmalardan bazıları şunlardır:

1. İlköğretim Müzik Dersi Ses Materyalleri Sergisi, Bolu 2003.

2. Müzik Dersinde Devinim ve DansBölümler Arası Orff Gösterisi, Bolu 2004.

3. Çocuklar İçin Müzik-Orff Çalgıları Dinletisi, Bolu 2005.

4. Okulöncesi ve İlköğretim Müzik Öğretmenleri İçin Atölye-Nesneler ve Ses Oyunları, İstanbul 2006.

\section{Uygulamada Karşıllaşılan Sorunlar}

İlgili derslere katılan öğrencilerin çok büyük çoğunluğu çalışmalar hakkında olumlu dönütler vermektedir. Eğlenerek öğrendiklerini bildirmekte, çocukların eğitimi için gerekli bilgi ve beceriler edindiklerini dile getirmektedirler. Öğrencilerin bir kısmı, kendilerine yönelik algılarında olumlu yönde değişimler olduğunu, içsel ve yaşamsal hareket alışkanlıkları üzerinde tekrar düşünme olanağı bulduklarını da vurgulamaktadırlar.

Bununla birlikte, çalışmaların hedeflenen genişlik ve derinlikte ve istenilen nitelikte sürmesini engelleyen bir kısım sorunlar da çözüm beklemektedir. Bunlar aşağıda özetlenmiştir:

1. Bazı malzemelerin, Orff ezgi çalgılarının ve Orff-Schulwerk didaktik kaynaklarının temininde yönetsel olarak yeterli finansman desteği verilememektedir.
2. Ders yapılan mevcut mekanlar, zemin gerektiği gibi kullanılamadığından OrffSchulwerk anlayışında bir çalışma için yeterli değildir. Bunun için fakülte dışındaki olanaklardan yararlanılma yoluna gidilmektedir. Fakat, bu durum her defasında ayrı organizasyon gerektirdiğinden, zaman kaybına yol açmaktadır.

3. Derslere katılan öğrenci sayılarının yüksek olması (yaklaşık 40 kişilik gruplar), aktif çalışma esnasinda grubun yönetimi ve denetimi ile değerlendirme açısından çeşitli zorlukları beraberinde getirmektedir.

4. Öğrencilerin büyük bölümünün öğretmen merkezli derse alışkın olması ve bilişsel öğrenmenin baskın olması, aktif çalışmaya geçiş süresini uzatmaktadır. Örneğin, dans ülkemiz kültürünün önemli unsurlarından birisi olmasına rağmen, birçok öğrencinin elementer müzik alıştırmalarına başlarken devinmekten çekinmesi, arka planda kalmak istemesi dikkat çekicidir. Bu tür sorunlar Müzik Eğitimi Anabilim Dalı̀nda yapılan çalışmalarda diğer bölümlere kıyasla daha az ortaya çıkmaktadır.

5. Müzik eğitimi öğrencilerinin müzik bilgilerinin ileri düzeye ulaşmış olması, yaratıcı çalışmalarda teorik şemalar içerisinde düşünmelerine sebep olmaktadır. Doğaçlamalarda bu bilgi birikimi yönlendirici veya sınırlayıcı olmakta, birçok kez ortaya çıkan ürünün kendiliğindenliği ve öğrenenin keşfedici arayışı olumsuz etkilenmektedir. Zihin Engelliler Eğitimi Anabilim Dalı 'nda yapılan çalışmalarda bu sorun daha az ortaya çıkmaktadır.

6. Seyrek karşılaş1lan bir sorun ise, çalg1 becerileri ileri seviyelere ulaşmış müzik eğitimi öğrencilerinin bazılarında ortaya çıkmaktadır. $\mathrm{Bu}$ öğrenciler, elementer çalışmaları basit bulmakta ve dolayısı ile Elementer Müzik Eğitimi'nin pedagojik önemini kavrayamayıp motivasyon eksikliği yaşamaktadırlar. $\mathrm{Bu}$ durumdaki öğrencilerin genel pedagojik donanımlarının da zayıf olması, bu tutumları pekiştirmektedir. 
7. Elementer müzik ve hareket çalışmalarının çok az sayıdaki derste sınırlı olarak yapılabilmesi, öğrencilerin kazanımlarını diğer derslerle ilişkilendirmesini ve tüm öğrenim yaşamı içinde canlı tutmasını zorlaştırmaktadır. Bunun sonucu olarak, bazı öğrenciler bu çalışmaların gereğine inanmamaktadırlar.

8. Okul Deneyimi ve Öğretmenlik Uygulaması dersleri çerçevesinde uygulama okullarına giden öğrenciler, kalabalık, sabit sıralara oturulan ve araç-gereç açısından az desteklenmiş sınıflarla karşılaştıklarında umutsuzluğa düşmekte, kazanımlarının işlevselliğini sorgulamaktadırlar. Bununla birlikte, okul çalışmalarının olumlu etkileri de olabilmektedir: öğrenciler kazanımlarını yaş gruplarının özellikleriyle öğrenme ortamında karşılaş̧tırabildiklerinden, umutsuz bakış açılarında kısmen değişim de gözlenmektedir.

\section{Sonuc}

Carl Orff'un Elementer Müzik ve Hareket Ĕgitimi tasarımı ve Orff-Schulwerk materyali, bireyin devinme, konuşma ve müzik yapma davranışları açısından bütüncül olarak eğitilip müziğe giriş yolu bulmasını sağlamayı amaçlar. Orff'un pedagojik fikirleri, 1930'lu yıllardan itibaren ilgi çekmiş, çocukların eğitimi açısından taşıdıkları önem fark edildiğinden pek çok ülkede kabul edilip yaşama geçirilmiş̧ir. Bu uluslararası tanınma sürecinde Günther Okulu, Orff Semineri ve Orff Enstitüsü’nün kurumsal katkıları ile birlikte, Orff ve çalışma arkadaşı Keetman`ın yurt dışında bizzat gerçekleştirdikleri çalışmalar da önemli bir rol oynamıştır.

Ülkemizde de bu eğitim anlayışından haberdar olma açısından geç kalınmamıştır. Bu yöndeki ilk adımlar 1950'li yıllarda atılmasına rağmen, OrffSchulwerk çeşitli sebeplerle eğitim/müzik eğitimi planlama ve uygulamalarımız içerisinde tüm bileşenleriyle resmi olarak yer alamamış, kurumsallaştırılamamış ve ülke çapında kullanılır hale getirilememiştir. Bundan dolayı, OrffSchulwerk uygulamaları uzunca yıllar girişimci kişilerin çabalarıyla sınırlı bir kitle tarafından sürdürülebilmiştir. Onun ülkemizde geniş çaplı tanınması ve çocukların hizmetine sunulması, sosyo-kültürel, sosyo-ekonomik ve eğitim politikalarıyla ilgili çok çeşitli etkenlerden dolayı 21. yüzyıla kalmıştır.

Orff un Elementer Müzik Eğitimi, duyuşsal (sensomotor), bilişsel (kognitiv), duygusal (affektiv), devinişsel (psychomotor) ve sosyal yönleriyle bir bütün olarak tanımlanan insanın niteliklerine uygun bir eğitim anlayışıdır. İnsanın kendi bedeninden ve kendini ifade araçlarından yola çıtığı için varlığı ile uyumludur ve onun için temel bir deneyimdir. Böylesine temel bir deneyimi geçirmek ülkemizde yetişmekte olan bireylerin de hakkıdır. Bundan dolayı, söz konusu çalışmaların okullarımızda ve okul müzik derslerinde kendi anlayışında yer alması için gerekli düzenlemeler yapılmalıdır.

Müzik öğretmenlerinin elementer anlayıştaki kazanımları, onların yetişmekte olan bireylere yaklaşımını etkileyip çocukların bütüncül eğitimini teşvik edeceğinden, öğretmen eğitimi programlarında ilgili çalışmaların yer alması tarafımızdan önemli görülmektedir. $\mathrm{Bu}$ çalışmaların çalma ve söyleme ile birlikte diğer yaratıcı müziksel davranışlar için motive edeceği de düşünülmektedir. Bunun için, kurumumuzda elementer müzik alıştırmaları öğretmen eğitimi amaçlarıyla tutarlılık gösterecek şekilde başlatılmıştır. $\mathrm{Bu}$ uygulamalarda öğrencilere teoriden daha çok yaşantı kazandırmak ön plandadır. Birden çok duyu işe koşularak, çeşitli aksiyon formları eşgüdümlü çalışılarak, bireysel çalışma yanı sıra sosyal öğrenme teşvik edilerek çok yönlü davranış oluşturma amacına hizmet edilmektedir. Çalışmalarda, öğrenciyi merkez alan, onun sorumluluk almasını, sürece aktif, şekillendirici ve yaratıcı olarak katılmasını, 
potansiyelini ortaya çıkarmasını sağlamayı amaçlayan modern yöntemler kullanılmaktadır.

Bu girişimlerle birlikte, sözü edilen uygulamalar belli dersler kapsamında ve o derslerin kendi içerikleriyle paralel olarak yürütüldüğünden, burada sunulan çalışmalardan da anlaşılabileceği gibi Orff-Schulwerk materyali tüm aşamalarıyla detaylı olarak çalışılamamaktadır. Yine de bu uygulamalar, beceri ve bilgilerini ilerleterek devam ettirmek isteyen öğretmen adayları için büyük ölçüde yönlendiricidir, Zihin Engelliler Öğretmenliği öğrencileri için de oldukça işlevsel olduğu düşünülmektedir.

Elementer müzik eğitimi süreci geleneksel ders biçimleriyle bire bir örtüşmediğinden, bu çalışmalarda çeşitli sorunlarla karşılaşılmaktadır ve bu olağandır. Mekan ve malzeme temininde yaşanan zorluklar bunların başında gelmektedir. Yine de, malzeme eksikliği Orff anlayışındaki çalışmaları başlatmak için engel değildir; çünkü Orff-Schulwerk in bazı boyutları tek bir gerece bile sahip olunmadan çalışılabilmektedir.

Uzun vadede çözülebilecek diğer sorunsal ise, öğrencilerin bir bölümünde görülen uyum problemi ve olumsuz tutumlardır. Öğrencilerin yaygın olarak alıştıkları öğretmen merkezli ve edilgen konumda bulundukları dersten uzaklaşıp, aktif ve yaratıcı olarak çalışmaları ve bu anlayışı içselleştirmeleri zaman almaktadır, buna direnç gösterilmektedir. $\mathrm{Bu}$ tür sorunların çözümü düşünce değişimine dayandığından, onlara sabırla yaklaşma, Orff Elementer Müzik, Hareket ve Konuşma Eğitimi konseptinin antropojen ve pedagojik temellerini anlatma ve tanitlama gerekmektedir. Ayrıca, uygulamaların ilk dönemlere alınması öğrencilerin akademik çalışmaya yoğunlaşmadan OrffSchulwerk'le tanışmasını sağlayacaktır. Bu tür bir düzenleme, öğrencilerin merakını ve keşfedici yaklaşımını olumlu yönde etkileyebilir ve müzik kuramsal şemaların doğaçlama sürecine olan biçimleyici etkisini azaltabilir. Böylece, bir yandan Elementer Müzik Eğitimi anlayışının doğasına yaklaşılırken, diğer yandan, bazı öğrencilerde yaşanan motivasyon bozukluğunun da önüne geçilmiş olabilir.

\section{Kaynaklar}

Aydın, H. (2006). Eğitim sisteminde modern ve postmodern modeller. Bilim ve Gelecek. 33, 60-69.

Bilen, S.; Özevin, B.; ve Uçal, E. (2003). Öğretmen yetiştirmede Orff öğretisi. Uluslararası Orff-Schulwerk Müzik ve Dans Pedagojisi Sempozyum Bildirileri. 110-120, İstanbul: Orff-Schulwerk Eğitim ve Danışmanlık Merkezi.

Calvin-Campbell, K. (02.03.1998): Supporting the development of the whole child through Orff Schulwerk, Montessori and multiple intelligences. Retrieved from http://eric.ed.gov/ERICDocs/data/ericdocs2 /content_storage_01/0000000b/80/24/b1/f5. $p d f$ on 06.12 .2006 .

Dinçer, M. (1988). Türkiye'de okulöncesi öğretim, ilköğretim ve ortaöğretim kurumlarında müzik eğitimi nasıl olmalıdır? I. Müzik Kongresi Bildirileri. 445-452, Ankara: Evren Ofset.

Georgiades, T. G. (1936): Das Orff-Schulwerk in Griechenland. Kugler, M. (Ed.) (2002): Elementarer Tanz - Elementare Musik. 228-229, Mainz: Schott Musik International.

Gersdorf, L. (1997). Carl Orff. (5. Basim). Hamburg: Rowohlt Taschenbuch Verlag.

Haselbach, B. (2002): Dorothee Günther. Kugler, M. (Ed.): Elementarer Tanz - Elementare Musik. 50-65, Mainz: Schott Musik International.

Holzheuer, R. (1979). Musik- und Bewegungserziehung. Heuss, G. E.; Rabenstein, R. (Ed.): Fachdidaktisches Studium in der Lehrerbildung. Grundschuldidaktik 1. 115-131, München: Oldenbourg Verlag. 
Jungmair, U. E. (2002). Orff-Schulwerk. Elementare Musik- und Tanzpädagogik im Sinne Carl Orffs. Orff-Schulwerk. Eğitim ve Danışmanlık Merkezi Info. 1, 8-11.

Jungmair, U. E. (2005). Zum Modellcharakter des Orff-Schulwerks. Orff-Schulwerk Eğitim ve Danışmanlık Merkezi Info. 7, 8-10.

Kalyoncu, N. (2002). Musikunterricht in der deutschen und türkischen Grundschule. Eine vergleichende didaktische Analyse. Frankfurt am Main ve diğerleri: Peter Lang Verlag.

Kalyoncu, N. (2004a). Abant İzzet Baysal Üniversitesi `nde Orff Ile Karşılaşma. OrffSchulwerk. Eğitim ve Danışmanlık Merkezi Info. 2004,5, 18-19.

Kalyoncu, N. (2004b). Müzik öğretmeni yeterlikleri ve güncel müzik öğretmenliği lisans programı. 1924-2004 Musiki Muallim Mektebi`nden Günümüze Müzik Öğretmeni Yetiştirme Sempozyum Bildirileri. Cilt II, 510-525, Isparta: Süleyman Demirel Üniversitesi Basımevi.

Kugler, M. (1995). Bewegung und Musik. Helms, S.; Schneider, R.; Weber, R. (Ed.): Kompendium der Musikpädagogik. 223240, Kassel: Gustav Bosse Verlag.

Kugler, M. (Ed.). (2002). Elementarer Tanz Elementare Musik. Die Günther-Schule München 1924 bis 1944. Mainz: Schott Musik International. Kültür Bakanlığ (1938). Ortaokul Programi. İstanbul: Devlet Basımevi.

Milli Eğitim Bakanlığı [MEB] (1948). İlk Okul Programı. İstanbul: Milli Eğitim Basımevi.

MEB (1952). Öğretmen Okullarl ve Köy Enstitüleri Programı. Ankara: Milli Eğitim Basımevi.

MEB (1962). İlkokul Programı Taslağı. Ankara: Ayyıldız Matbaası.

MEB (1968). İlkokul Programı. İstanbul: Milli Eğitim Basımevi.

MEB (1994). İlköğretim Kurumları Müzik Dersi Öğretim Programı. Ankara: Milli Eğitim Basımevi.
Nykrin, R. (1994). Elementare Musikerziehung. Helms, S.; Schneider, R.; Weber, R. (Ed.): Neues Lexikon der Musikpädagogik. Sachteil. 52-54, Kassel: Gustav Bosse Verlag.

Orff, C. (1930/31). Bewegungs- und Musikerziehung als Einheit. Kugler, M. (Ed.) (2002): Elementarer Tanz Elementare Musik. 169-172, Mainz: Schott Musik International.

Orff, C. (1931/32). Gedanken über Musik mit Kindern und Laien. Kugler, M. (Ed.): Age., 173-177.

Orff, C. (1932/33). Elementare Musikübung, Improvisation und Laienschulung. Kugler, M. (Ed.): Age. 183-192.

Orff, C.; Keetman, G. (1950-54). OrffSchulwerk. Musik für Kinder. Cilt 1-5, Mainz: Schott Verlag.

Öztürk, A. (2005). Türk Eğitim Sisteminin Orff Ögretisi (Orff-Schulwerk) Ile Tanışmasında Ilk Elçi: Muzaffer Arkan. Orff-Schulwerk Eğitim ve Danışmanlık Merkezi Info. 2005 (7), 18-21.

Peterßen, W. H. (2000). Handbuch Unterrichtsplanung. (9. Basım). München: Oldenbourg Schulbuchverlag.

Regner, H. (1995). Musik für Kinder. Üben und Musizieren. 1995 (4), 3-6.

Say, A. (Ed.). (1985). Orff Çalgıları. Müzik Ansiklopedisi. Cilt 4, 999-1002, Ankara: Müzik Ansiklopedisi Yayınları.

Sey-Uluç, R. (2002). Liz Teyze Çocuk Yuvası'ndan LERA'ya. Orff-Schulwerk Eğitim ve Danlşmanlık Merkezi Info. 2002 (2), 8-10.

Türk Sanayicileri ve İşadamları Derneği [TÜSİAD] (2005). Doğru başlangıç: Türkiye'de Okul Öncesi Eğitim. Alınan adres:

http://www.tusiad.org/haberler/basin/duyur uno681.pdf. tarih 14.11.2006. 
ABANT IZZET BAYSAL ÜNIVERSITESI ÖRNEĞI

Uçan, A. (1996). Gazi Yüksek Öğretmen Okulu Müzik Bölümü Müzik Alanı Birinci Yıl Programinın Değerlendirilmesi. Ankara: Çağrı Matbaası.

Uçan, A. (2003). Türkiye`de Müzik Eğitiminin Gelişimi, Orff Okul Öğretisi’nin Tanımı Uygulanımı- Uyarlanımı ve Orff
Anlayışıyla Temel Müzik Eğitiminin Genel Durumu. Uluslararası Orff-Schulwerk Müzik ve Dans Pedagojisi Sempozyumu. 10-39, İstanbul: Orff-Schulwerk Eğitim ve Danışmanlık Merkezi. 


\title{
Summary Orff-Schulwerk Practices In Turkey The Sample of Abant Izzet Baysal University
}

\author{
Nesrin KALYONCU* \\ Abant İzet Baysal University
}

\section{Elemental Music and Dance Education design} and Orff-Schulwerk material by Carl Orff purposes that individual is educated as a whole and finds an access route to the music. Since it is realized that this design is of vital importance for the education of children, Elemental Music and Dance Education has widely been used in the most countries. Being aware of this insight of education in our country dates back to 1950's. However, this has not been able to be located and institutionalized within the context of our education/music education planning and implementation and not been able to be made available in country-wide with its all components by the various reasons. Hence, Orff-Schulwerk applications have been continued by a limited group thanks to efforts of the persons having enterprising spirit for long years. Widely knowing this in our country and submitting it into children's service have been postponed to $21 \mathrm{st}$ century by socio-cultural reasons, socioeconomical reasons and a great variety of reasons in respect of education policies.

Elemental Music Education by Orff is an educational insight suitable for the attributes of human being who is defined as a whole in its sensomotor, cognitive, emotional, psychomotor and social aspects. It is well-adjusted to the existence of human being and a fundamental experience for human since it has emerged from people's own body and tools with which they express themselves. Individuals growing up in our country deserve to have such a fundamental experience, as well. Therefore, necessary arrangements should been made to place the said studies in Turkish schools and musical lesso at the school.

It is important the taking place of OrffSchulwerk studies in musical teacher training programs in order to let the teachers of the future get acquainted with this kind of education concept. Furthermore, it increasingly becomes a necessity that the music teacher candidates are equipped also with very various musical behavior patterns besides the musical field knowledge and teaching knowledge in order to respond to the requisites of the curricula that are planned to be implemented in schools currently. In addition, Elemental Music and Dance Education greatly respond to demands of Multiple Intelligence Theory which affects today's educational implementations. Starting with these opinions, elementary musical practices have been started in Bolu Abant İzzet Baysal University in 2002. Thus, a new link has been added to the chain of the elemental music studies performed in a restricted numbers of universities in our country. In this article, objectives, contents and methods of the said implementations are described and the problems caused by the studies are stated. Actual studies are intensively performed in Music Education Department in the Faculty of Education. The central Music Teacher Education Undergraduate Program conducted in this 
department does not include any lessons that fully cover Elemental Music and Dance Education. The conducted implementations are integrated into the lessons such as "Game, Dance and Music", "Instruments for Music Lesson" and "Music Teaching Methods". Orff-Schulwerk is also considered in a more limited context within the scope of the "Music Teaching" lessons in the Department of Mental Disabilities Education.

In these implementations causing students to earn a practice rather than theory is generally in the front row. Objectives of the study can be summarized as recognizing Elemental Music and Dance Education in general terms, having musical lives in elementary conception and levels, coordinating auditory, visual, tactual and kinesthetic perception and improving habits for individual and common working. Furthermore, it is deemed to be important that teacher candidates gains consciousness and basic information so that they can use Orff's pedagogical ideas in school music lessons as content and method.

A wide range of activities such as conversation, motion, singing, playing instruments, transformation etc. are considered as complex and creative and multidirectional attitude formation is encouraged in the studies. Methods which will focused on students and allow them to take responsibilities, participate as active, former and creative individuals, and reveal their potentials are used in the implementations.

Together with such attempts, since implementations in question are being conducted in parallel with the specified lessons and their own contents, Orff-Schulwerk materials cannot be studied in details with its all stages. Nevertheless, these practices are greatly guiding for the teacher candidates who are willing to continue their skills and knowledge and functional for the students of the Department of Mental Disabilities Education.

As elementary musical practices do not efficaciously match traditional lesson processes, various issues are faced in these studies. Certain problems are accompanied by arriving the students at an advanced level with regard to musical theoretical aspects, as well as the supply of location and material. This negatively affects interests and descriptive insights of the students and reduces their motivation. Acquired musical theoretical schemes of the students shapes and affect the improvisation process. In addition, it takes time that students move away from teachercentered lessons and studies in an active and creative manner, and internalize such insights. 